\title{
Teilhard de Chardin's Vision of Science, Religion and Planetary Humanity: A Challenge to the Contemporary World
}

\author{
Ursula King \\ uking@blueyonder.co.uk
}

\section{Abstract}

Teilhard de Chardin (1881-1955) was a great thinker, scientist, and mystic he was above all an extraordinary human being whose inspiring vision still remains far too little known. He visited South Africa twice, in 1951 and 1953, to undertake palaeontological research and collaborate with South African colleagues. Throughout his life, but especially towards its end, he was much interested in the future of planetary humanity and he always stressed the importance of seeing, of having a vision that pulls us forward and upward. For him, life is vision. I examine how this vision - embracing science, religion and the future of humankind - presents a challenge to the contemporary world and an inspiration to create a better future for all.

I first look at our world in crisis, dominated by science, but politically fragmented, suffering from much injustice, poverty and violence. Where are we going? Teilhard's evolutionary, convergent and universalist thinking can be a guiding light for the contemporary world to move forward.

At the present state of crisis, planetary humanity is faced, more than ever before, with the responsibility for its further self-evolution. Has the human species the evolutionary capacity for developing its life to a higher stage, for truly transformative action to create greater collaboration and unification, more universal peace and justice? This is a decisively critical question, for to evolve further is no longer just an option, but an imperative.

What are the spiritual energy resources needed for the further development of the human community, especially the necessary zest for life, the all-transforming power of love and compassion available in order to 


\section{Ursula King}

develop an environmentally and ecologically sound way of life to ensure the wellbeing of all people and the planet? In order to be able to evolve further, we need a new spiritual awakening, and a deeply mystical, action-oriented spirituality in the contemporary world. I hope to show that Teilhard's integral vision, rooted both in modern science and a fervent faith, can be an empowering vision for us all.

Keywords: science, religion, planetary humanity, vision, the future of humankind, self-evolution, evolutionary capacity, universal peace and justice, spiritual energy, zest for life

In truth, at the rate the consciousness and the ambitions of the world are increasing, it will explode unless it learns to love. The future of the thinking earth is organically bound up with the turning of the forces of hate into forces of love (Teilhard de Chardin, Hymn of the Universe 1971:125).

It is a special honour to write an essay for this Festschrift celebrating Martin Prozesky's $70^{\text {th }}$ birthday. He and I have been in professional contact over many years, meeting on different occasions, especially during his visits to England. But most of all I am deeply grateful to him for inviting me in 1993 to undertake some teaching at what was then still the University of Natal. Thus I owe him especially my very enriching visit and travels around different parts of South Africa at that time, meeting many South African specialists in Religious Studies and Theology, followed by another visit in 1996. I have chosen to contribute a paper based on my long-standing research on the French Jesuit scientist-mystic Pierre Teilhard de Chardin (1881-1955) who, late in life, in 1951 and 1953, came to South Africa twice, spending each time several months there. He undertook geological and palaeontological fieldwork, met South African colleagues and visited all the important paleontological collections in different museums around the country. In his Letters from a Traveller several descriptions of his experience can be found. On leaving Johannesburg in September 1953, he wrote to his brother: '... whatever part of South Africa you visit, it's a magnificent country, and I can't leave it - and the friends I have 
made there - without a pang of regret' ${ }^{1}$.

Teilhard de Chardin was a great thinker, a great scientist, a great mystic - he was above all an extraordinary human being whose inspiring vision still remains far too little known. He so much stressed the importance of seeing, of having a vision that pulls us forward and upward. For him, life $i s$ vision. As he wrote in the Foreword on 'Seeing' in his great book The Human Phenomenon:

Seeing. One could say that the whole of life lies in seeing - if not ultimately, at least essentially...See or perish. This is the situation imposed on every element of the universe by the mysterious gift of existence. And...to a higher degree, this is the human condition $^{2}$.

In order to show what a challenge Teilhard's vision presents today, I shall begin with some general comments about the critical state of the world; then reflect on planetary humanity at the crossroads in order to consider what spiritual resources we possess for ensuring the future wellbeing of people and planet. I will conclude by summing up some of the major aspects of Teilhard's life and vision that can help a world in crisis to move constructively forward.

\section{A World in Crisis: Where are we Going?}

We are living in a highly interconnected, global world with many seemingly insoluble problems: there is the runaway growth of the human population, the maldistribution of resources, the existence of widespread military and structural violence, the absence of stable peace. There are also the profoundly unjust inequalities linked to the growing imbalance between the extremes of abject poverty and those of ostentatious wealth, and there is the threat of ecological disaster looming large on the horizon. Many of these crises affect African countries as much or even more than other countries around the globe.

${ }^{1}$ Teilhard de Chardin (1996: 346), in his Letters from a Traveller. Detailed descriptions of his first and second visits are found in Claude Cuénot's Teilhard de Chardin. A Biographical Study (1965: 314-26; and 327-46).

${ }^{2}$ P. Teilhard de Chardin, The Human Phenomenon. A New Edition and Translation of Le Phénomène humain (1999: 3); hereafter cited as HPh. 


\section{Ursula King}

Our age is often described as an age of unbelief, with its growing secularism, especially in the northern hemisphere, where many people appear to be spiritually impoverished, marked by a crass materialism, much greed, and a loss of transcendence. Yet at the same time we know of many people with a deep ethical commitment to transformative social and ecological action, attracted to a new spirituality emerging from within the secular. We recognize not only uncertainty, doubt and loss of moral certitude, but also other signs that indicate a sincere search for meaning and a willingness to experiment. Thus it is not primarily abstract religious thought and dogma that are most important, but lived religious experience which is vital wherever it is found, whether inside or outside traditional religious institutions.

This emphasis on experiment and experience which is such a strong characteristic of our scientific approach to the external world has also become more important for the worlds of our mind and soul. Contemporary religiosity is characterised by a great search for interiority and a new inwardness, a longing to explore our 'inner space' which can provide a true counterweight to our dazzlingly dizzy scientific probes into outer space. This search for a contemplative depth-dimension within us responds to a great contemporary need to heal a hectic and disjointed outward life marked by over-activity, unrest and much superficiality in human relations. But this hunger and thirst for interiority, meditation and prayer of the quiet are not the only characteristics of contemporary life. They are accompanied by a search for a greater outward collaboration and unification at all levels, whether one thinks of growing international social and political movements, international development projects, peace or ecological movements, to name but a few.

The great intellectual adventures of modern times have primarily been connected with scientific and technological inventions. These represent an ongoing, continuing quest for the exploration and understanding of the world around and within us, of cosmos, nature, life, and human beings - their immense diversity and richness, and the social, cultural and spiritual evolution of the human species.

The scientific quest can be described as a quest for ever more knowledge, a quest which expands our perception and experience of the boundaries of the real; it ultimately seeks the unity and interrelatedness of all knowledge. But like all human endeavours, the pursuit of science is characterised by profound ambivalence and many ethical problems. Whilst the search for the unity of knowledge is its positive side, science can also have a 
dark, negative side, for its driving force can be the lust for power and domination, for exploitation and destruction. The power of analytical science is so immensely great today that, if ruthlessly pursued to the limits of its possibilities and unchecked by ethical criteria, it can destroy the natural environment and human life itself.

Teilhard de Chardin saw perhaps less of this dark side of modern science, its power for evil and destruction, than we perceive today. His own practice, praise and love of science were undertaken from a position of responsibility and deep reverence, permeated by a religious spirit. $\mathrm{He}$ understood the scientific quest as a search for the unity of knowledge and saw it at its deepest level as closely related to the deep human longing for union that expresses itself in the scientific, religious and mystical quest.

Yet he was also never tired of pointing out how our understanding of science is much too narrow, particularistic and fragmentary. Its power of analysis must now be matched by attempts at synthesis, by a more holistic and global way of thinking. Scientists have analysed the physical-biological as well as the mental and psychic aspects of the human being, but have not given the same attention to the moral and spiritual needs of people. This is where Teilhard saw everything from a wider, more universal perspective and in need of transformation. Science and mysticism are not in opposition to each other but ultimately interrelated. For him the rational and mystical are much closer to each other than generally thought. Teilhard's holistic vision is grounded in both science and faith; both are approached from an all-embracing perspective that is evolutionary, convergent, and universalist. Its comprehensiveness and depth offer a tremendous challenge to our contemporary world. It is a challenge that can empower people to think, act and live differently - not simply to live, but what Teilhard calls to 'superlive': to live a fuller, better, more rewarding life shared with one's fellow human beings.

Through his temperament and travels, and through his detailed scientific studies of the history of human life on earth, Teilhard developed an extraordinary sense of the earth as a whole, and of humankind as one. He spoke early of the 'planetisation' of humankind, or what we today would call 'globalisation'. One of the strongest expressions of this sense of the earth and of humanity as one is found in his 1931 essay 'The Spirit of the Earth' ${ }^{3}$. He describes this as 'the passionate sense of common destiny that draws the

${ }^{3}$ Published in his book Human Energy (1969: 19-47); hereafter cited as HE. 


\section{Ursula King}

thinking fraction of life ever further forward', and speaks of 'the evolution of a greater consciousness' whereby human thought 'introduces a new era in the history of nature' which involves a renewal of life, a 'crisis of birth', which he saw linked to a process of raising the whole 'edifice of life to a new stage"4. He saw the whole world and all peoples within it as one. Beyond the external forces of unification or globalisation, brought about by scientific research, economics, finance, political power, media communication or even militarization, Teilhard was looking for the 'miracle of a common soul' (HE, 35 ) for a greater convergence and union of the diverse elements of humanity. This cannot be achieved without the powers of love and compassion. It is an ideal that cannot be reached without developing the spirit of the earth, nor can it be found without what he calls 'the arising of God', that is to say, the continuous development of the idea of God on earth, or what some might perceive as the openness to the presence of the spirit.

Teilhard recognized that there may exist resistance 'to open our hearts wide to the call of the world within us, to the sense of the earth' (HE, 31). Yet this sense can reveal to us 'the newly freed energies of love, the dormant energies of human unity, the hesitant energies of research' (HE, 32). He explains these in both metaphorical and religious terms. Love is described as 'the most tremendous and the most mysterious of the cosmic forces'. 'Huge, ubiquitous and always unsubdued', love is a 'wild force', but also 'a sacred reserve of energy' - it is 'like the blood of spiritual evolution' (HE, 33, 34). As to human unity, human beings often experience more of an 'instinctive repulsion' and distance from each other than genuine attraction; we cannot truly love millions of strangers but are often profoundly disturbed by the plurality of human beings we encounter. The 'spirit of the earth' and the experience of human unity seem at present more of a dream than a reality, yet Teilhard felt that this 'sense of, this feeling for greater human unity is now 'in process of formation"; it is "the irresistible pressure which unites people at a given moment in a passion they share' (HE, 35 - my translation). This creates a movement towards human convergence and union through a new form of love practiced through mutual 'interlinking' rather than mere personal attraction $^{5}$.

\footnotetext{
${ }^{4}$ These quotations are found in HE, 31, 27, 28, 37.

5 The French original reads 'l'amour d'interliaison, au-dessus de l'amour d'attrait'; see L'Énergie Humaine (1962: 44).
} 
Teilhard's remarks of more than eighty years ago (1931) may seem incredibly over-optimistic today, especially when we think of some of the controversial applications of contemporary scientific research, and the excesses of material production and over-consumption. They invite strong critique, but to be fair, Teilhard also diagnosed many symptoms of a growing crisis in different spheres of human activity. He wrote in the same essay:

From the economic and industrial point of view the crisis is evident .... Too much iron, too much wheat, too many automobiles - but also too many books, too many observations; and also too many diplomas, technicians and workmen - and even too many children. The world cannot function without producing living beings, food, ideas. But its production is more and more patently exceeding its powers of absorption and assimilation ... we must ask what this excess production means. Is the world condemned, as it grows, to automatic death by stifling beneath its own excessive weight?

He answered this question in the negative and interpreted the numerous problems in the contemporary world as a 'crisis of birth'. He finished his essay on 'The Spirit of the Earth' with the powerful, visionary statement:

The age of nations has passed. Now, unless we wish to perish we must shake off our old prejudices and build the earth .... The more scientificcally I regard the world, the less can I see any possible biological future for it except the active consciousness of its unity (HE, 37f).

Teilhard's way of thinking is thoroughly shaped by the evolutionary dynamic of becoming. For him, the world is going somewhere! His essay 'How I Believe' (1934), also from the 1930s, is preceded by an epigraph that sums up his vision in evolutionary terms:

I believe that the universe is an evolution.

I believe that evolution proceeds towards spirit.

I believe that spirit is fully realized in a form of personality.

I believe that the supremely personal is the universal Christ ${ }^{6}$.

${ }^{6}$ Teilhard de Chardin (1971: 96). For Teilhard's discovery of evolution, see King's ‘A Vision Transformed' (2013: 590-605). 


\section{Ursula King}

In other words, evolutionary processes are universal; they embrace all realities, from the depths of matter to the height of spirit, from the cosmic to the human and divine which Teilhard perceived everywhere and encountered above all in the incarnate and cosmic Christ. The universe was not simply an object of scientific enquiry for him, but a living, evolving reality. The world of nature, 'Mother Earth', which he passionately loved and embraced as something alive, pulsating with energy and growth, revealed to him a greater presence, an environment suffused with the divine.

Many passages in his writings express a strong sense of the interdependent unity and organicity of all living things. He wrote in 1942 that through studying the history of the cosmos and of all forms of life,

... we have gradually come to understand that no elemental thread in the Universe is wholly independent in its growth of its neighbouring threads. Each forms part of a sheaf; and the sheaf in turn represents a higher order of thread in a still larger sheaf - and so on indefinitely ....

This is the organic whole of which today we find ourselves to be a part, without being able to escape from it...in countless subtle ways, the concept of Evolution has been weaving its web around us. We believed that we did not change; but now...we are becoming aware of the world in which neo-Time, organising and conferring a dynamic upon Space, is endowing the totality of our knowledge and beliefs with a new structure and a new direction ${ }^{7}$.

He sees humanity moving into a new environment, into 'a world that is being born instead of a world that is' (FM 88), with a new relationship between matter and spirit, a new humanism, and a new understanding of God - complementary movements which perhaps mark 'the beginning of a new era for humankind' (FM 96).

\section{Planetary Humanity at the Crossroads}

This is the rise of a truly planetary humanity where the increasing complexity of matter and material organisation results in an accompanying rise of

7 See his essay 'The New Spirit' (1942) in P. Teilhard de Chardin, The Future of Man (1965: 82-96). See esp. 85; hereafter FM. 
consciousness and spiritual awareness. For Teilhard this is connected with the mutual embeddedness of the biosphere with what he called the 'noosphere', the specific human sphere of thinking and action, today sometimes described as the 'planetary mind'. This also includes important aspects of what we today call eco-justice and social justice, animated above all by the transformative and healing powers of love. For Teilhard, the noosphere has also a deeply spiritual dimension which he described as 'the divine milieu', a field of divine energy and a central focal point which is both immanent and wholly transcendent at the same time.

Teilhard was a great scientist. He qualified in geology, was well acquainted with biology, physics and chemistry, and excelled in palaeontology, the study of human origins, where he gained an international reputation. But the more closely he studied ancient fossils, the more he turned away from the past and developed a fascination with the present, and even more the future. Reflections on the future of humankind and its further social, cultural and spiritual development feature prominently in his work. He expressed with clarity and forcefulness that we are one humanity, with one origin, and one destiny. We are also a group of humans that has not yet reached maturity in terms of its possibilities. Its immense problems somehow resemble the turmoils of youth. Teilhard argued that all of humankind bears a profound sense of responsibility for the shape of its own future, and that humanity's future must be developed in close interrelation with all forms of life, with the whole of nature in its global and planetary dimensions.

On whatever continent we live today, it is becoming obvious that ever more people are developing a new planetary vision and sense of the earth. The general awareness of the history of the earth, of life and the great biodiversity of our planet is much greater today than ever before. The public media and the environmental movement have each contributed to this increased knowledge of the richness, but also the vulnerability, of our biosphere and human habitat. So many of us experience the living world as a marvellous and ever so vulnerable environment that is constantly faced by threats and disasters.

A new consciousness is emerging in the world in connection with our understanding of the story of the universe, linked to our knowledge of the immensity of space, the depth of time, and the complexity of life and of human cultures in a globally interconnected world. This awe-inspiring story is beautifully told in the film 'The Journey of the Universe. The Epic Story of Cosmic, Earth, and Human Transformation' produced by Mary Evelyn Tucker, 


\section{Ursula King}

John Grim and Brian Swimme ${ }^{8}$. It demonstrates clearly that the story of humanity emerges out of the story of the universe and is an integral part of the vast, interconnected web of life covering our planet Earth.

The discovery of universal evolutionary processes implies a profound revolution in human thinking and action; it gives rise to an altogether new awareness of the universal processes of evolutionary becoming that now call for the further self-evolution of humanity. This implies that humanity bears a tremendous responsibility for the future evolution of the whole human species and the planet itself.

Teilhard asked how can we be 'architects of the future'? How can we develop a better, higher life for the human community? He reflected on the conditions and criteria by which human beings might become more united economically, politically, and spiritually. How will the human species evolve further? His book The Future of Man carries the motto: 'The whole future of the Earth, as of religion, seems to me to depend on the awakening of our faith in the future' (FM, 7). He combined such faith in the future with what he called 'faith in man', that is, a faith in the further development of human beings, and in the greater global collaboration and unity among the peoples of the earth. He spoke of a new threshold in the development of human consciousness and organization, not simply a search for the continuity of life or mere survival. What is needed is the development of life to a higher stage which involves an effort to create a higher form of life, a more unified humanity.

The problem of the future is paramount for the present: will humanity survive or be annihilated, will it progress or stagnate? Teilhard thought we have no decisive evidence for either hope or despair, but we have today perhaps more reasons to be pessimistic than he was more than sixty years ago. One thing is certain: we need to find the right road, make the right choices and put our will into effective action to create the right world for humanity today. Teilhard was certainly convinced that despair cannot provide the necessary energy for action, but hope can.

In a postscript written to The Human Phenomon eight years after its completion he describes the social phase of human evolution as 'the rise toward a collective step of reflection', a second stage of hominisation whose final success is by no means certain, although this process has certain irreversible

8 See Swimme \& Tucker's The Journey of the Universe. Available at: www.JourneyoftheUniverse.org. 
features, so that he can ask how 'can we fail to see in this revealing association of technical arrangement and psychic centration that it is forever the same great force at work (although in a proportion and depth never attained before) - the very force that made us?' (HPh 219, 220).

Humanity now bears full responsibility for its own future; both education and scientific research play a great role in this. It is also an immense challenge - the kind of future we will get depends to a large extent on the quality of people who shape it. Teilhard emphasised the need for a 'homo progresssivus' (FM, 137), for future-oriented, future-affirming beings with a wide, open awareness who have the energy of thought, the vision and perception to recognise the problems of the future and find their solutions, and who possess the necessary energy and will to action for putting them into practice.

This is a bold vision entailing tremendous challenges and risks - a vision that may instil fear in some of us and invite others to new experiments and great daring. Teilhard was a pioneer in calling attention to the problems of the future; again and again he insisted on the need for a scientific study of and consciously planned work for the future. The social integration of people around the globe into some kind of 'super-humanity' presupposes the further self-evolution of the whole human species towards a higher order. Like some of his scientific colleagues Teilhard took it for granted that a basic mutation has already taken place in modern post-Darwinian, post-Marxian and postFreudian consciousness, but he postulates yet another necessary mutation: a greater awareness of humanity's necessary collectivity and the emergence of a higher collective consciousness to form a higher, new collaborative reality, just as the individual brain is something over and above the innumerable cells it consists of.

Teilhard's firm personal belief in a finally successful outcome of evolution was directly related to his detailed scientific knowledge, but his interpretation of the overall direction and ultimate goal of evolution was ultimately grounded in his fervent Christian faith and deep Christian hope, in the light of which he interpreted all the data of evolution available to him.

In an essay called 'The Grand Option' (1939; in FM, 37-60), he discussed the possible paths humanity might take next, finding itself at the threshold of higher human socialisation. What road should be taken? Should it be,

1. That of pessimism or optimism? 


\section{Ursula King}

2. If the latter, would it be an optimism of withdrawal or an optimism of evolution?

3. Should the further evolution of the human community occur in terms of more plurality or higher unity?

For Teilhard, the right choice consists always in the necessary action for the higher unification and unity of humanity. This is the overall direction of the further evolution of the human species ${ }^{9}$. In his view, humanity has practically lived for most of human history without analysing its own activities; it has existed from hand to mouth in the pursuit of more or less limited aims, guided more by instinct than by reason. But now, with the expansion of our thought, the environment of human action has changed; with our new awareness of the immensities of space and time, of past and future, of living in an evolutionary and convergent universe we experience a sense of 'universal unification'.

Teilhard saw these general, irreversible developments as indications 'that the spirit has acquired an added dimension', that a 'wave of new life' penetrates all our undertakings and that everything is animated 'with a flow of Presence and Love', a love which he also described as 'the free and imaginative outpouring of the spirit over all unexpected paths' (FM, 55). He spoke of a,

general and irreversible readjustment of the values of existence ... showing our accession, beyond all ideologies and systems, to a different and higher sphere, a new spiritual dimension.

He also referred to 'the greatness of the present moment', to a 'new world into which we are being born' (FM, 60). These inspiring words come from a great visionary thinker seeing far ahead. Yet this text makes painful reading, if set into the socio-political context of 1939 when these words were written, six months before the outbreak of the Second World War. Yet Teilhard was fully aware of the length of time and the many battles it might take for planetary humanity to evolve to this higher stage of life. He admitted that 'further ideological clashes and moral dissensions lie in wait for us as we go forward; and also further unions and further triumphs (FM, 60).

As always, he remained a prophet of hope to the last, presenting an

${ }^{9}$ In what follows I paraphrase FM, 59-60. 
empowering vision to suffering humanity. Moreover, after the end of the Second World War, he spent another decade working out what resources we can draw upon for nurturing the zest for life and the desire to evolve in order to create a worthwhile future for all people and the planet. Given the immense problems of the contemporary world, we are more painfully aware than ever before that planetary humanity is now truly at the crossroads: much decisive action is needed to find acceptable solutions for our immense social, political and environmental problems. Which of Teilhard's ideas can challenge and inspire us in our work for the future?

\section{Spiritual Resources for the Future Wellbeing of People and Planet}

An enormous number of material and spiritual resources are needed to ensure a viable future for humanity. Certain external and internal conditions have to be fulfilled if human and natural life are to remain in balance. If these conditions are not met, life on earth will fail. Teilhard was well aware of our precarious situation, as clearly stated in his late work Man's Place in Nature, written in Paris in 1950, after the Second World War, when he commented:

Should the planet become uninhabitable before mankind has reached maturity; should there be a premature lack of bread or essential metals; or, what would be still more serious, an insufficiency, either in quantity or quality, of cerebral matter needed to store, transmit, and increase the sum total of knowledge and aspirations that at any given moment make up the collective germ of the noosphere: should any of these conditions occur, then, there can be no doubt that it would mean the failure of life on earth; and the world's effort fully to center upon itself could only be attempted again elsewhere ... ${ }^{10}$.

Teilhard often speaks about the need to examine all available energy resources, especially those required for nourishing and sustaining human growth and action. Central to maintaining the dynamic of action is the zest for

${ }^{10}$ Teilhard de Chardin, Man's Place in Nature (1966: 118). 


\section{Ursula King}

life, the will to live and love life - this is an indispensable requisite for the continuity of life, especially in the form of a higher life, and also for the development of a planetary ethic. Enemy number one is indifference and boredom, the loss of a taste for life, the absence of inner resources, and the danger of dropping out of collaborative action altogether. Teilhard highlighted the existing contradiction,

that all over the earth the attention of thousands of engineers and economists is concentrated on the problem of world resources of coal, oil or uranium - and yet nobody... bothers to carry out a survey of the zest for life: to take its 'temperature', to feed it, to look after it, and...to increase $\mathrm{it}^{11}$.

The taste and zest for life, for all life, human and non-human, is essential for the future of our planet ${ }^{12}$. Similarly to the way in which we are concerned to preserve the biodiversity of life forms, we need also to take conscious account of and responsibility for maintaining the rich 'noospheric' diversity of religious and spiritual ideas, since they provide us with irreplaceable resources for feeding the zest for life.

Teilhard favoured a closer contact and dialogue between members of different faiths, and encouraged their active collaboration in making the world a better place through promoting a greater integration of the diverse elements of humanity. After his return from China, he was actively involved in interfaith dialogue in Paris between 1947-1950, but this is generally little known. On several occasions he reflected on the contribution of different world faiths to the ongoing convergence of religions ${ }^{13}$.

${ }^{11}$ Teilhard de Chardin, Activation of Energy (1970:236; hereafter AE).

${ }^{12}$ An extensive discussion of Teilhard's understanding of 'the zest for life' is found in my two essays 'Feeding the Zest for Life: Spiritual Energy Resources for the Future of Humanity' in Thierry Meynard, S.J. (ed.): Teilhard and the Future of Humanity (2006: 3-19); and 'The Zest for Life: A Contemporary Exploration of a Generative Theme in Teilhard's Work' in Ilia Delio (ed.), From Teilhard to Omega: Co-creating an Unfinished Universe (2014: 184202).

13 See Ursula King, The Spirit of One Earth. Reflections on Teilhard de Chardin and Global Spirituality (1989), esp. Chapter 7, 'Exploring 
In looking at its resources, the human community does not give the same attention to its available spiritual energy resources as it does to the calculation of its available material energy reserves. Yet spiritual energy resources are indispensable for sustaining persons and planet; human beings bear the responsibility to locate them, use them for their sustenance, and increase them. The religious and philosophical traditions of the world - our global religious heritage - contain irreplaceable resources on which we must draw to nourish our zest for life, sustain the biosphere, foster the growth of the noosphere, and advance the balanced integration of the diverse groups and nations of the global community. Nowhere is this better expressed than in Teilhard's 1950 address on 'The Zest for Living' (AE, 229-43). At the deepest level, the zest for life is linked to an act of faith:

... what is most vitally necessary to the thinking earth is a faith - and a great faith - and ever more faith.

To know that we are not prisoners.

To know that there is a way out, that there is air, and light and love, somewhere, beyond the reach of all death.

To know this, to know that is neither an illusion nor a fairy tale. That, if we are not to perish smothered in the very stuff of our being, is what we must at all costs secure. And it is there that we find what I may well be so bold as to call the evolutionary role of religions (AE, 238).

He stressed that contemporary religious needs are different from those in the past, and that our historically new situation and consciousness require a new spirituality and a new image of God. A spirituality mainly concerned with the individual is no longer sufficient; what is needed is a faith in humanity and

Convergence: The Contribution of World Faiths'; and Chapter 8, 'Teilhard's Association with the World Congress of Faiths, 1947-1950'. I have examined the themes of the convergence of religions, of religion and evolution, and of spiritual energy resources in relation to the rise of a new mysticism more fully in my book Teilhard de Chardin and Eastern Religions: Spirituality and Mysticism in an Evolutionary World (2011). The Foreword was written by Joseph Needham. A more comprehensive treatment of contemporary spirituality in a pluralistic global world is found in my work The Search for Spirituality: Our Global Quest for Meaning and Fulfilment (2009). 


\section{Ursula King}

the earth. Teilhard's own spirituality was deeply rooted in what he called the 'divine milieu', a deep faith in a divine centre and heart of the world that suffuses every context and environment with the energy, presence, and grace of the spirit whose dynamic action animates the entire universe. Thus the noosphere is not only a sphere of human evolution, but one that bears the traces of divine love and transfiguration. Love is for him both a human task and an 'effect of 'grace' and 'revelation", 14 . To create stronger bonds within the human community and bring about a better world for all, the energies of love - the highest form of human energy and 'the blood of spiritual evolution' (HE, $34)$ - in all their different dimensions and practical expressions are what is needed most.

We cannot advance the world and the flourishing of people and planet without a zest for life. He described this zest as "nothing less than the energy of universal evolution' but, at the human level, the feeding and development of this energy 'is to some degree our responsibility' (AE, 231, 232).

This theme preoccupied him until the day of his death. In one of his last essays, the profoundly personal and mystical text 'The Christic' (See HM, 80-102), written in March 1955, he speaks of 'the primordial sources of the Energy of Evolution' which modern science has discovered, but also of the need for humanity 'to find a way to increase the Drive of Evolution':

If humanity is to use its new access of physical power with balanced control, it cannot do without a rebound of intensity in its zest to act, in its zest to seek, in its zest to create (HM, 96-97; my translation).

Teilhard de Chardin's vision of how to feed 'the zest for life' within ourselves and within the world is truly empowering and inspirational, if we really want to seed and grow a better future for the whole of humanity, and not only for its privileged members. There now exists a growing number of 'noospheric institutions' which are working in ever so many fields for the good of the inhabitants of the earth. New processes of global networking are constantly emerging, and the possibilities for a 'global-interlinking-through-

${ }^{14}$ AE, 242. I have discussed Teilhard's understanding of love in 'Love - A Higher Form of Human Energy in the Work of Teilhard de Chardin and Sorokin', in Zygon: Journal of Religion and Science (2004: 77-102). 
love' that Teilhard first perceived in the 1930s, have grown exponentially through the fast advances of electronic means of communication and other ways of networking around the globe, and that also includes multiple new ways of understanding spirituality today. This is an important general point to make, but it also applies to the African situation where religious pluralism is vividly present, from multiple indigenous religious traditions to the richness of many different Christian, Muslim and other faiths.

\section{The Challenge of Teilhard's Life and Vision for the Contemporary World}

The greatest challenge of all lies perhaps in Teilhard de Chardin's own example, in the powerful testimony of his life's experience in which a scientific and spiritual vision of the world, humanity and God are so deeply interwoven. Teilhard was blessed with an extraordinarily rich life, full of adventures of mind and spirit, yet in his own church he was marginalized and made to suffer, ostracized for his integral vision of combining the insights of evolutionary science with those of a fervent Christian faith. In the words of his former Jesuit superior, Fr René d'Ouince SJ, Teilhard was truly 'a prophet on trial' in the church of his time ${ }^{15}$. Today he has become somewhat more accepted and better known than sixty years ago, but he is also still largely ignored, especially among Roman Catholics.

Few people will know that already in the early twentieth century Teilhard de Chardin reflected critically on cultural and religious diversity, global interdependence and a growing 'planetisation' of the human community. He reflected on biodiversity and the fragility of life on the planet, but also on the significant contribution of China in shaping the future of humanity. It was amidst the killing fields of the First World War that he first perceived the rise of human interthinking and interaction. He eventually described this as the rising of the 'noosphere', of a layer of interlinking connections that encircles our planet like the geosphere, the biosphere, the atmosphere and other layers surrounding the earth. For some people this extraordinary foresight makes Teilhard almost a patron saint of what we now know as the internet.

${ }^{15}$ See René d'Ouince, Un prophète en process: Teilhard de Chardin dans l'Église de son temps (1970). 


\section{Ursula King}

To sum up the unity of Teilhard's life and thought, it seems to me most appropriate to characterise him by one metaphor he so frequently used himself - that of fire, flame, and spark. He truly was a 'Spirit of Fire" ${ }^{16}$ who followed the 'road of fire' throughout his life and writings. He was a man of deep thought and faith, but also of great depth of feeling - a passionate thinker rather than a merely intellectual one. This is evident from many of his letters, diary entries and essays, especially the spiritual autobiography The Heart of Matter (1950), written late in his life ${ }^{17}$.

But this integral vision is there from the very first essay on 'Cosmic Life' $(1916)^{18}$ which celebrates 'communion with God through the world'. Traditionally, religious people have often sought communion with God by separation and escape from the world, whereas many secular people, immersed in the world, have pursued the development of the world or immersion in nature without a link to the divine. For Teilhard, both these 'fires' or 'energies' need to be combined in 'communion with God through the world' where God is loved like the world and the world is loved as something divine, as animated by the spirit of God. In many ways this is an ancient Christian vision going back to the cosmic hymns of St Paul and the early Greek fathers, but Teilhard translates this into a partly new vision rooted in a dynamic, evolutionary universe.

Another important, unusual element of his spirituality is his emphasis on the feminine which he also calls the 'unitive element'. By this he refers particularly to the love he had experienced through the influence of women in his life - initially the nurturing presence of his mother, the love of his sisters and cousins, and later his lasting friendships with a number of outstanding women $^{19}$. It was through these experiences that he really felt that the universe

${ }^{16}$ I have used this as the title of my biography, Spirit of Fire: The Life and Vision of Pierre Teilhard de Chardin (revised edition 2015).

${ }^{17}$ This essay forms part of a collection of articles published in a book of the same title. See P. Teilhard de Chardin, The Heart of Matter (1978: 15-79).

${ }^{18}$ Found in P. Teilhard de Chardin, Writings in Time of War (1968: 13-71).

${ }^{19}$ See for example the important correspondence with his cousin, Marguerite Teillard-Chambon, in P. Teilhard de Chardin, The Making of a Mind: Letters from a Soldier-Priest 1914-1919; and also the correspondence with the American sculptor Lucile Swan, The Letters of Teilhard de Chardin and Lucile Swan (1993). For a discussion, see Ursula King, The Letters of Teilhard de 
is suffused by love. Love is the secret thread that runs through the universe, the outpouring of the spirit over all unexplored paths.

Teilhard argued that humanity has to harness the powers of love and develop them to a much greater potential than ever before. Human beings need love as much as they need light, oxygen and vitamins. We need love to be well, whole, and connected in communion and union. His understanding of love refers not only to love between individuals, but envisages a new kind of love that creates the strongest bonds across the whole human community. This is what Teilhard understood by building up the earth: the amorization of planetary humanity and the whole universe. Teilhard can only be understood in the wider context of evolution, providing us with a new cosmology and a new Earth consciousness. It is as if all his thoughts were nested within ever expanding circles of the universe. This may be the reason why Thomas Merton entitled his essay on Teilhard's Divine Milieu 'The Universe as Epiphany'. Teilhard provides a great example of 'seeing anew' by celebrating a vision at once cosmic, human, and divine ${ }^{20}$.

He discovered the heart of God in all creation, in the heart of matter, of life, and of humanity. The divine heart beats at the centre of an evolving cosmos and for Teilhard it was above all encountered in the cosmic Christ 'clothed in the glory of the world'. Living in the divine milieu means discovering fire through the all-transforming power of love, forging a new spirituality in and for an evolutionary world, a spirituality that is linked to a new mysticism of action, love, and unification.

Teilhard once described himself as 'consumed by fire from within'. His spirituality may be described as a pan-christic fire and heart mysticism ${ }^{21}$,

Chardin and Lucile Swan. A Personal Interpretation. Published as Teilhard Studies Number 32 (Fall 1995) by The American Teilhard Assocation.

20 This great cosmotheandric vision provides the structure for his autobiographical essay 'The Heart of Matter' (see note 17 above). This cosmotheandric vision is found in the letters of St. Paul and the early Christian fathers, but it also plays a great role in Raimon Panikka's work. See Ursula King, 'The Cosmotheandric Vision of Pierre Teilhard de Chardin and Raimon Panikkar', in Teilhard Studies Number 72 (2016).

${ }^{21}$ See Ursula King, 'Consumed by Fire from Within: Teilhard de Chardin's Pan-Christic Mysticism in Relation to the Catholic Tradition, in The Heythrop Journal (1999: 456-77). 


\section{Ursula King}

but also a mysticism that in Kathleen Duffy's poignant expression is closely interwoven with 'seeing the inner face of evolution' 22 .

\section{Conclusion}

Our contemporary worldview is above all shaped by the immense power of modern science and technology as well as global economics. This affects all areas of life and has a deeply transformative impact on all traditional cultures and beliefs. The rise of evolutionary thinking from the nineteenth century onwards has had a tremendous impact on the world, but relatively few religious thinkers have systematically explored the importance of evolution for their religious beliefs and traditions. Pierre Teilhard de Chardin is an outstanding exception here as is, in the context of other religious traditions, the Indian philosopher and mystic, Sri Aurobindo, and within Islam, Mohammed Iqbal.

But where is Teilhard's legacy debated today, his prophetic voice listened to? Where are his ideas experienced as energising and empowering? These questions will be answered differently, depending on where one lives and is coming from. Even after a thorough, critical sifting, Teilhard's ideas still provide many valuable perspectives for fresh creative thinking, whether on the evolutionary understanding of the universe and planetary humanity, or in relation to contemporary process thought, or in the context of the ecological movement and sustainability debates. Although global thinking has much advanced on environmental issues, elements of a truly balanced ecological spirituality can already be found in many of Teilhard's writings. In fact, some of the powerful statements in the new Earth Charter, aimed to ensure the future of the community of life on our planet, would have deeply resonated with $\operatorname{him}^{23}$.

It is particularly Teilhard's personal experience and understanding of spirituality and mysticism, centred on the cosmic Christ, and a deeply personal Christian faith related to the dynamic of the contemporary world, which attract many of his followers. Yet even in contemporary works on spirituality Teilhard

${ }^{22}$ See Kathleen Duffy, Teilhard's Mysticism: Seeing the Inner Face of Evolution (2014).

${ }^{23}$ See the essays edited by Celia Deane-Drummond, Pierre Teilhard de Chardin on People and Planet (2006). I contributed 'One Planet, One Spirit: Searching for an Ecologically Balanced Spirituality’ (2006: 74-95). 
is rarely given the careful attention he deserves as a creative thinker in this field, and as someone who embodies some of the best Christian spiritual practice.

It is of considerable interest to know that especially during the 1960s, when Teilhard's book The Human Phenomenon (then first misleadingly mistranslated as The Phenomenon of Man (1959) attracted wide international attention, several well-known African leaders, such as Julius Nyerere from Tanzania, Kenneth Kaunda from Zambia, Milton Obote from Uganda and Leopold Senghor from Senegal, read Teilhard's work, and some of them quoted from it. Attracted by Teilhard's futuristic vision of the world as a 'civilization of the universal' developing through panhuman convergence, they empathized with his view of the complementarity of the world's civilizations. According to a recent commentator, Senghor saw in Teilhard's 'civilization of the universal' a future,

in which African traditional values and cultural forms could exist in solidarity with a global community that emphasized reciprocity and similitude. Senghor believed that if Teilhard's approach could be realized, and human races are complementary, then Africans should strive to remain true to their origins and not be too quick to break from past ideals in order to embrace western modes of living, thinking, and behaving ${ }^{24}$.

There are many 'generative ideas' in Teilhard's work - ideas that can generate and bring about change. His thinking and vision can greatly contribute to and widen out contemporary discussions on global developments in many areas of human activity, from economics and politics to education, ethics, peace and eco-justice as well as religion and spirituality, to list some of the most obvious and urgent issues. Let us recognize the unique legacy of Pierre Teilhard de Chardin and rejoice that the twentieth century has brought forth such a man of faith and dynamic vision wherein science, religion and mysticism are so creatively interrelated. Far from being outlived and passé, his ideas may attract a renewed interest today, since they can enrich our

${ }^{24}$ Quoted from Charlotte Walker-Said's blog 'The Global Reach of Teilhard's Legacy' on the 'Teilhard Project', available at: www.teilhardproject.com (Accessed on 12 May 2014.). 


\section{Ursula King}

discussions and inspire transformative action to ensure the future of people and planet. His life and work provide a strong witness to the life-giving powers of a deep religious faith that relates strongly to the hopes, desires, needs and strivings of the twenty-first century world we live in. To conclude with Teilhard's own words: 'In truth, at the rate that consciousness and its ambitions are increasing, the world will explode unless it learns to love. The future thinking of the earth is organically bound up with the transformation of the forces of hatred into forces of love ${ }^{25}$.

\section{References}

Cuénot, C. 1965. Teilhard de Chardin: A Biographical Study. London: Burns \& Oates.

Deane-Drummond, C. (ed.) 2006. Pierre Teilhard de Chardin on People and Planet. London and Oakville: Equinox Publishing.

d'Ouince, R. 1970. Un prophète en process: Teilhard de Chardin dans l'Église de son temps. Paris: Aubier-Montaigne.

Duffy, K. 2014. Teilhard's Mysticism: Seeing the Inner Face of Evolution. Maryknoll, NY: Orbis Books.

King, U. 1989. The Spirit of One Earth: Reflections on Teilhard de Chardin and Global Spirituality. New York: Paragon House.

King, U. 1989. Chapter 7: Exploring Convergence: The Contribution of World Faiths. In The Spirit of One Earth: Reflections on Teilhard de Chardin and Global Spirituality. New York: Paragon House.

King, U. 1989. Chapter 8: Teilhard's Association with the World Congress of Faiths, 1947-1950. In The Spirit of One Earth: Reflections on Teilhard de Chardin and Global Spirituality. New York: Paragon House.

King, U. 1995. The Letters of Teilhard de Chardin and Lucile Swan. A Personal Interpretation. Published as Teilhard Studies Number 32,Fall, by The American Teilhard Assocation.

King, U. 1999. Consumed by Fire from Within: Teilhard de Chardin's PanChristic Mysticism in Relation to the Catholic Tradition. The Heythrop Journal 40,4: 456-77.

25 Teilhard de Chardin, The Vision of the Past (1966: 214). A somewhat different translation is found in P. Teilhard de Chardin, Hymn of the Universe. (1971: 125). 
Teilhard de Chardin's Vision of Science, Religion and Planetary Humanity

King, U. 2004. Love - A Higher Form of Human Energy in the Work of Teilhard de Chardin and Sorokin. Zygon: Journal of Religion and Science 39,1: 77-102.

King, U. 2006. Feeding the Zest for Life; Spiritual Energy Resources for the Future of Humanity. In Meynard, T.S.J., (ed.): Teilhard and the Future of Humanity. New York: Fordham University Press.

King, U. 2006. One Planet, One Spirit: Searching for an Ecologically Balanced Spirituality. In Deane-Drummond, C. (ed.): Pierre Teilhard de Chardin on People and Planet. London and Oakville: Equinox Publishing.

King, U. 2008/2009. The Search for Spirituality: Our Global Quest for Meaning and Fulfilment. New York \& Norwich: BlueBridge \& Canterbury Press.

King, U. 2011. Teilhard de Chardin and Eastern Religions: Spirituality and Mysticism in an Evolutionary World. Foreword by Joseph Needham. Mahwah, NJ: Paulist Press.

King, U. 2013. A Vision Transformed: Teilhard de Chardin's Evolutionary Awakening at Hastings. The Heythrop Journal 54,4: 590-605.

King, U. 2014. The Zest for Life: A Contemporary Exploration of a Generative Theme in Teilhard's Work. In Delio, I. (ed.): From Teilhard to Omega:

Co-creating an Unfinished Universe. Maryknoll, NY: Orbis Books.

King, U. 2015. Spirit of Fire: The Life and Vision of Pierre Teilhard de Chardin. Revised Edition. Maryknoll, NY: Orbis Books.

King, U. 2016. The Cosmotheandric Vision of Pierre Teilhard de Chardin and Raimon Panikkar. Teilhard Studies Number 72, Spring, published by the American Teilhard Association.

Swimme, B.T. \& M.E. Tucker. The Journey of the Universe. Documentary. Yale University Online Classes Open to the Public. Available at: www.JourneyoftheUniverse.org.

Teilhard de Chardin, P. 1959. The Phenomenon of Man. London: Collins. Teilhard de Chardin, P. 1961. The Making of a Mind: Letters from a Soldier.

Hague, R. (ed.). New York: Harper \& Row.

Teilhard de Chardin, P. 1962. L'Énergie Humaine. Paris: Éditions du Seuil. Teilhard de Chardin, P. [1942] 1965. The New Spirit. In The Future of Man.

London: Collins.

Teilhard de Chardin, P. 1966. Man's Place in Nature. London: Collins. Teilhard de Chardin, P. 1966. The Vision of the Past. London; Collins. Teilhard de Chardin, P. 1969. Human Energy. London: Collins. 


\title{
Ursula King
}

Teilhard de Chardin, P. 1970. Activation of Energy. London: Collins.

Teilhard de Chardin, P. 1971. Christianity and Evolution. London: Collins.

Teilhard de Chardin, P. 1971. Hymn of the Universe. London: Collins Fount Paperbacks.

Teilhard de Chardin, P. 1978. The Heart of Matter. London: Collins.

Teilhard de Chardin, P. 1993. The Letters of Teilhard de Chardin and Lucile

Swan. (King, T.M. S.J. \& M. Gilbert eds.). Washington: Georgetown University Press.

Teilhard de Chardin, P. 1996. Letters from a Traveller. London: Collins.

Teilhard de Chardin, P. 1999. The Human Phenomenon. A New Edition and Translation of Le Phénomène humain by Sarah Appleton-Weber. Brighton \& Portland: Sussex Academic Press.

Teilhard de Chardin, P. n.d. Writings in Time of War. London: Collins. Available at: https://archive.org/details/WritingsInTimeOfWar

Walker-Said, C. 2014. Blog: The Global Reach of Teilhard's Legacy. The 'Teilhard Project'. Available at: http://www.teilhardproject.com/ (Accessed on 12 May 2014.).

\author{
Ursula King \\ Institute of Advanced Studies \\ University of Bristol \\ England \\ uking@blueyonder.co.uk
}

